\title{
Gas hydrate distributions in sediments of pockmarks from the Nigerian Margin - Results and interpretation from shallow drilling
}

\author{
Wei Jiangong ${ }^{1, ~}{ }^{*}$, Pape Thomas ${ }^{1}$, Sultan Nabil ${ }^{2}$, Colliat Jean-Louis ${ }^{3}$, Himmler Tobias ${ }^{1,2}$, \\ Ruffine Livio ${ }^{2}$, De Prunelé Alexis ${ }^{2}$, Dennielou Bernard ${ }^{2}$, Garziglia Sebastien ${ }^{2}$, Marsset Tania ${ }^{2}$, \\ Peters Carl A. ${ }^{1,5}$, Rabiu Abdulkarim ${ }^{4}$, Bohrmann Gerhard ${ }^{1}$
}

\footnotetext{
${ }_{1}^{1}$ MARUM, University of Bremen, Klagenfurter Str., 28359 Bremen, Germany

2 IFREMER, Département REM, Unité des Géosciences Marines, F- 29280 Plouzané, France

${ }^{3}$ Total, Pau, av. Larribau, France

${ }_{5}^{4}$ Nigeria Institute for Oceanography and Marine Research, Nigeria

${ }^{5}$ Department of Earth and Planetary Sciences, Macquarie University, Sydney, NSW 2109, Australia

* Corresponding author : tel.: +49(0)421 21865055 ; email addresses : jwei@marum.de ; yourbabyface2010@hotmail.com
}

\begin{abstract}
:
A joint research expedition between the French IFREMER and the German MARUM was conducted in 2011 using the R/V Pourquoi pas? to study gas hydrate distributions in a pockmark field (1141 - 1199 meters below sea surface) at the continental margin of Nigeria. The sea floor drill rig MeBo of MARUM was used to recover sediments as deep as $\mathbf{5 6 . 7 4}$ meters below seafloor. The presence of gas hydrates in specific core sections was deduced from temperature anomalies recorded during continuous records of infrared thermal scanning and anomalies in pore water chloride concentrations. In situ sediment temperature measurements showed elevated geothermal gradients of up to $258{ }^{\circ} \mathrm{C} / \mathrm{km}$ in the center of the so-called pockmark $A$ which is up to 4.6 times higher than that in the background sediment $\left(72{ }^{\circ} \mathrm{C} / \mathrm{km}\right)$. The gas hydrate distribution and thermal regime in the pockmark are largely controlled by the intensity, periodicity and direction of fluid flow. The joint interaction between fluid flow, gas hydrate formation and dissolution, and the thermal regime governs pockmark formation and evolution on the Nigerian continental margin.
\end{abstract}

Keywords: gas hydrate, pockmark, chloride profile, infrared thermal imaging, fluid flow, Nigerian continental margin, MeBo drill rig 


\section{Introduction}

41 Pockmarks are circular to elongated seafloor depressions which are often associated with

42 fluid flow from the subsurface (Judd and Hovland, 2007). Submarine pockmarks with

43 various sizes, shapes and state of activity have been widely discovered at different water

44 depths (e.g. Bünz et al., 2003; Chen et al., 2010; Dondurur et al., 2011; Pilcher and

45 Argent, 2007; Pinet et al., 2010; Sahling et al., 2008; Sun et al., 2011; Ussler et al., 2003).

46 In addition, buried paleo-pockmarks found during seismic investigations were proposed

47 to be associated with periodic fluid flow activity in the past (Andresen et al., 2008).

48 Depending on the local geological conditions, several mechanisms have been suggested

49 to explain the process of pockmark formation. Researchers tend to agree that pockmarks

50 are directly or indirectly caused by upward fluid flow from the deep subsurface, through

51 moderate to violent processes (Chand et al., 2012; Gay et al., 2006a; Gay et al., 2006b;

52 Hartwig et al., 2012; Moss et al., 2012; Paull et al., 2008; Riboulot et al., 2013; Rise et al.,

53 1999). In particular on continental margins, methane oversaturated in upward migrating

54 fluids reacts under high pressure and low temperature in shallow sediment to form solid

55 gas hydrate (Matsumoto et al., 2011; Sloan and Koh, 2007). The structural properties of

56 gas hydrate, like its fabric, and the hydrate saturations in the sediment, are largely

57 controlled by the intensity and distribution of fluid flow and by the sediment properties,

58 including permeability and strength (Abegg et al., 2007). Moreover, fluid migration

59 patterns are changed by pore space blocking caused by gas hydrate formation (Bangs et

60 al., 2011; Riedel et al., 2006). The interaction between fluid flow, gas hydrates and host

61 sediment increases the complexity of the pockmark system and is of significant 
62 importance when studying the formation and evolution of deep-water pockmark located

63 in the gas hydrate stability zone (GHSZ).

64 Sultan et al. (2010) proposed an initial model for the formation of individual pockmarks

65 on the Nigerian continental margin. Based on gas hydrate findings in shallow sediments

66 and numerical modeling of the dynamic response of the gas hydrate to changes in gas

67 concentrations underneath the gas hydrate occurrence zone (GHOZ), gas hydrate

68 formation and dissolution was suggested to be the major control for the evolution of these

69 pockmarks. In order to gain further insight, a joint research expedition (Guineco-MeBo)

70 between the French IFREMER and the German MARUM with the R/V Pourquoi pas?

71 and the portable sea floor drill-rig MeBo was conducted in 2011. The major objective of

72 the expedition was to reveal gas hydrate distributions in even deeper sediments, which

73 eluded sampling with common sampling techniques (e.g., long piston cores) before.

74 In this study, gas hydrate distributions in sediments of selected pockmarks were

75 determined using infrared (IR) thermal scanning of core liners and pore water chloride

76 analysis. Furthermore, the impact of fluid flow and gas hydrate formation/dissolution on

77 controlling the geothermal regime and evolution of the pockmarks is discussed.

\section{2. Geological settings}

79 Our study area is a pockmark field located within the Gulf of Guinea on the continental

80 margin offshore Nigeria (Fig. 1). This continental margin is undergoing slow deformation

81 by gravity tectonism that initiated in response to both, rapid seaward progradation and

82 loading huge amount of sediment (Damuth, 1994). Damuth (1994) distinguished this area 
83 into three subareas based on the structural styles: 1) an upper extensional zone, 2) an

84 intermediate translational zone, and 3) a lower compressional zone. The pockmark field

85 studied in this paper is located in the translational zone which is characterized by diapirs

86 underneath. Examples of seismic recordings of shale diapirs in this area can be found in

87 Damuth (1994) and Cohen and McClay (1996).

88 The Nigerian continental margin is an active fluid flux area as indicated from various

89 seafloor features, such as pockmarks, mud volcanoes, gas hydrates and carbonate

90 concretions (Bayon et al., 2007; Brooks et al., 2000; Graue, 2000; Hovland et al., 1997).

91 Formation of such authigenic carbonates is typically attributed to the anaerobic methane

92 oxidation (AOM; Ritger 1987). Pronounced bottom simulating reflectors (BSR),

93 demonstrating the boundary between the base of the GHSZ and free gas underneath, were

94 reported (Cunningham and Lindholm, 2000). Such BSRs indicate the presence of gas

95 hydrates related to high methane flux towards shallow sediments caused by fluid

96 migration (Hovland et al., 1997). In addition, gas chimneys found in the subsurface were

97 proposed to serve as pathways for fast hydrocarbon migration between reservoirs and the

98 seafloor (Heggland, 2003).

99 The pockmark field, comprising the pockmarks A and C studied herein, lies at water

100 depths between 1141 and 1199 m. Pockmark A (Fig. 1C) is a slightly NE-SW elongated

101 seafloor feature with a hummocky topography in the center. The hummocky area

102 corresponds to high multibeam backscatter (George and Cauquil, 2007) which may

103 indicate the occurrence of shallow gas hydrates, free gas and/or authigenic carbonates

104 (Carson et al., 1994). Pockmark C (Fig. 1D) is a pockmark cluster composed of at least 
105 three pockmarks $(\mathrm{C} 1-\mathrm{C} 3)$. Shallow gas hydrates were found widely in this pockmark

106 field which might contribute to the formation of the pockmarks (Sultan et al., 2010).

107 Authigenic carbonates were also recovered from different depths in these pockmarks

108 (Sultan et al., 2010).

\section{3. Material and methods}

\section{$110 \quad 3.1$ MeBo drilling}

111 The mobile drilling system MeBo (Freudenthal and Wefer, 2013) was deployed from the

$112 \mathrm{R} / \mathrm{V}$ 'Pourquoi pas?' to drill 12 cores of up to $56.74 \mathrm{~m}$ in length in the pockmark field

113 between 1141 and 1199 m water depth (Fig. 1; Table 1). Seven drill sites were located in

114 and around pockmark A (Fig. 1C), with five sites in the central part (GMMB06, 07, 08,

11510 and 11) and two in the periphery (GMMB03 and 12). Two drill sites (GMMB01 and

116 02) were located outside (NW) pockmark A. Further three drill sites (Fig. 1D) were

117 located in pockmark C1 (GMMB04), pockmark C2 (GMMB05), and SE of pockmark C2

118 (GMMB09), respectively.

\section{$119 \quad 3.2$ Infrared thermal imaging of MeBo cores}

120 Infrared (IR) temperature profiles of the $2.52 \mathrm{~m}$-long MeBo core liners were obtained for

12110 drill sites in order to document the gas hydrate distribution in the MeBo cores. Images

122 for GMMB10 were not interpreted due to their low quality. The core liners were removed

123 from the core barrels immediately after recovery on deck. After a quick cleaning of the

124 liner surfaces, pictures were taken with an IR camera (ThermaCam SC 640 camera, FLIR

125 Systems) for documenting temperature variations. The temperature measurements of the 
126 IR system ranged from $-40{ }^{\circ} \mathrm{C}$ to $+120{ }^{\circ} \mathrm{C}$ and the precision of the camera was $0.1{ }^{\circ} \mathrm{C}$ at

$12730{ }^{\circ} \mathrm{C}$ with the accuracy of $\pm 2{ }^{\circ} \mathrm{C}$. Each thermal scan covered approximately $60 \mathrm{~cm}$ depth

128 range of the core. Five to six pictures including a spatial overlap of about $10 \mathrm{~cm}$ were

129 taken from each liner in less than one minute.

130 For an individual drilling station, all IR images were combined in one figure to display

131 the temperature distribution for the entire core surface. The raw data were converted and

132 exported as bitmap format using the ThermaCAM ${ }^{\mathrm{TM}}$ Researcher Professional software.

133 The bitmap files were processed using commercially available graphical software. All IR

134 images were merged consecutively, considering distinct hot or cold spots as reference

135 points. Temperatures along the central axis of the cores were extracted from the IR

136 images to obtain temperature logs (Fig. 2). Surface temperatures of core liners containing

137 sediment devoid of gas hydrates were considered as background temperature. At each

138 drilling station, background temperatures varied slightly (ca. $1-2{ }^{\circ} \mathrm{C}$ ) between individual

139 liners due to different in situ sediment temperatures and/or slightly different times

140 required for individual liner handling (equilibration with ambient temperature of $\approx 30{ }^{\circ} \mathrm{C}$

141 on ship's deck). Thus, the specific background temperature was assigned to each core

142 liner individually.

143 The difference between liner surface temperature and background temperature $(\Delta \mathrm{T})$ was

144 calculated to interpret the content of the cores. In order to obtain a better visualization

145 and to minimize the artifacts for further analysis, only anomalies with $\Delta \mathrm{T}>+1^{\circ} \mathrm{C}$ were

146 considered as voids in the liner and $\Delta \mathrm{T}<-2{ }^{\circ} \mathrm{C}$ were considered to represent hydrate-

147 bearing sediment, as hydrate dissociation is an endothermic process. 


\section{$148 \quad 3.3$ Pore water chloride and sulfate analysis}

149 Pore water was extracted using Rhizon samplers (Seeberg-Elverfeldt et al., 2005), which

150 consists of a thin tube made up with hydrophilic porous polymer with pore diameters of 151 approximate $0.2 \mu \mathrm{m}$. The Rhizon samplers were pushed into the sediment through holes 152 drilled through the plastic liners. 10 or $20 \mathrm{ml}$ plastic syringes were connected to the 153 sampler to create a vacuum and collect the pore water. Extracted pore water was split, 154 prepared for various analyses, and stored in the refrigerator or reefer. Sulfate and chloride 155 concentrations were measured on-board by using ion chromatography (861 Advanced 156 Compact IC, 837 IC Eluent Degasser, and Advanced Sample Processor by Metrohm).

157 For several MeBo stations, seawater-derived sulfate in detectable concentrations was not 158 only found in near-surface sediments but also in deeper layers. This was unexpected 159 because sulfate is typically depleted below the sulfate-methane interface (SMI) due to

160 AOM. Moreover, since measured sulfate concentrations below the SMI scattered 161 considerably, we assumed that the presence of sulfate in these core sections were artifacts 162 caused during the core drilling/handling procedure. Therefore, concentrations of chloride 163 were re-calculated assuming the absence of sulfate below the SMI. This procedure caused 164 changes in absolute chloride concentrations of $<20 \%$ but affected trends in chloride 165 profiles insignificantly.

\section{$166 \quad 3.4$ In situ temperature measurements}

167 In-situ temperature measurements were conducted in pockmark A using autonomous 168 miniaturized temperature loggers (MTLs) from ANTARES Datensystem GmbH 
169 (Germany), which have already been used successfully during previousstudies (Römer et

170 al., 2012; Feseker et al., 2009; Pape et al., 2011). Five temperature sensors were mounted

171 on outriggers attached to the cutting barrel of a 6 m-long gravity corer according to

172 Feseker et al. (2009). Distances between the loggers were $100 \mathrm{~cm}$ and the logging time

173 interval was set to $5 \mathrm{sec}$. For each deployment, the gravity corer was held 50 meters

174 above the seafloor for three to four minutes to measure the water temperature for

175 calibration purposes of each MTL. Based on these measurements the standard deviation

176 of the five loggers was calculated to be smaller than $0.008{ }^{\circ} \mathrm{C}$ (Table 2). At each station,

177 the loggers were left in the sediment for about 15 minutes (Fig. 5) after penetration of the

178 gravity corer to adjust to the sediment temperature. The absolute penetration depths could

179 be estimated from mud smear on the gravity corers or on the cable. By using linear

180 regression individual temperatures recorded with the MTLs and assumed penetration

181 depths were used to calculate the site-specific geothermal gradients.

\section{4. Results}

183 MeBo was deployed 12 times in total during the entire cruise. Depending on the lithology

184 as well as on gas and gas hydrate contents, the recovery of the drill cores ranged between

$18560 \%$ and $94 \%$ with a mean of $81 \%$. The cores comprised homogenous hemipelagic dark

186 greyish clay with sporadic authigenic carbonate concretions. Distinct depth-changes or

187 lateral variations of sediment grain sizes were not observed. Sediments with elevated

188 water content, which was attributed to ex situ gas hydrate dissociation, were observed at

189 different depths without regularity. No relation between gas hydrate distributions and

190 sediment grain sizes became obvious. 


\section{$191 \quad 4.1$ Infrared thermal imaging}

192 Infrared (IR) temperature profiles of core liners were established for most of the drill sites.

193 The only exceptions were station GMMB01 and GMMB02 outside of pockmark A since

194 indications for the presence of gas hydrates in sediments within the penetration depth

195 (53.3 meters below seafloor (mbsf)) at these drill sites were missing in seismic profiles

196 (Sultan et al., 2010). The assumption of the gas hydrates absence in these sediments was

197 confirmed by the subsequent pore water chloride profiling (see chapter 4.2).

198 Comparison of IR images with lithological core descriptions and high-resolution core

199 photographs showed that thermal regimes of the MeBo cores were mainly determined by

200 the core contents. This is exemplary shown for core GMMB06 (Fig. 2). Since the in situ

201 temperature of sediment $\left(\sim 4.5^{\circ} \mathrm{C}\right)$ was significantly lower than that of the upper water

202 column (up to $\sim 28^{\circ} \mathrm{C}$ ) and the atmosphere $\left(\sim 30^{\circ} \mathrm{C}\right.$ ), the cores were continuously warmed

203 up during the core recovery and handling on deck. Liners filled with sediment exhibited

204 intermediate temperatures of $23-25{ }^{\circ} \mathrm{C}$ (Fig. 2A), depending mainly on the duration they

205 were exposed to the water column and air before being imaged. These temperatures were

206 considered as background.

207 Cores containing dissociating gas hydrates yielded prominent cold anomalies since 208 hydrate dissociation happening during core recovery and handling is an endothermic 209 process. The temperature decrease is mainly influenced by the volume of gas hydrate

210 pieces and the decomposition speed. The extent of cold temperature zones reflects in

211 many ways the fabric of gas hydrates in the liners. Disseminated gas hydrates are prone

212 to dissociation in a relatively short time. After a very short time of dissociation-induced 
213 cooling which occurs relatively homogenously throughout a respective core section

214 temperature re-increases. Because of the relatively small amount of water released during

215 decomposition of disseminated hydrates, residual sediments often show a moussy fabric

216 (Weinberger et al., 2005) and exhibit moderate negative $\Delta \mathrm{T}$ of $-3{ }^{\circ} \mathrm{C}$ to $-4{ }^{\circ} \mathrm{C}$ (Fig. 2B).

217 In contrast, nodular gas hydrates, massive hydrate layers or hydrate-filled fractures

218 usually occurring in distinct intervals reveal stronger negative $\Delta \mathrm{T}$ of up to $-10{ }^{\circ} \mathrm{C}$ (Fig.

219 2C). Decomposition of such hydrate fabrics principally takes much longer time than that

220 of disseminated hydrates because of both, their comparably smaller surface area and the

221 resulting higher efficiency of the self-preservation effect (Sloan and Koh, 2007). During

222 decomposition of nodular/massive hydrates the residual sediment might become very

223 soupy because of the high volume of hydrate water released.

224 Voids or gaps defined as empty intervals in the liners are often due to gas expansion.

225 They are typically represented by positive $\Delta \mathrm{T}$ of $+2{ }^{\circ} \mathrm{C}$ to $+4{ }^{\circ} \mathrm{C}$ (Fig. $2 \mathrm{~A}$ and $2 \mathrm{C}$ )

226 because the effective heat capacity of the gas/air filled liner strongly differs from that of

227 sediments and the temperature gets into equilibrium with the ambient air rapidly. Voids

228 within gas hydrate-bearing sediments (Fig. 2C) are generated by gas expansion likely

229 caused by gas release from hydrate dissociation. In contrast, voids within non-hydrate

230 sediment (Fig. 2A), are likely caused by methane release from the dissolved phase due to

231 the pressure drop during core recovery. High-temperature patches with absolute

232 temperatures of more than $30{ }^{\circ} \mathrm{C}$ as shown in Fig. $2 \mathrm{~A}$ are core handling artifacts.

233 Since the IR thermal patterns of the cores are mainly controlled by their contents, they

234 were classified into four groups (Fig. 3). 


\section{IR-temperature pattern 1: Sediment without gas hydrates}

236 Homogenous hemipelagic sediment was represented by moderate temperatures of 23-

$23725^{\circ} \mathrm{C}$ (Fig. 2A). It was present in the top few meters of all cores (from 1.2 mbsf in 238 GMMB11 to 38.5 mbsf in GMMB09). It also occurred at the bottom of some cores below 239 the gas hydrate occurrence zone (GHOZ), including GMMB03, GMMB05, GMMB08 240 and GMMB12 (Fig. 3).

\section{IR-temperature pattern 2: Sediment with gas hydrate}

242 Gas hydrate-bearing sediments showed relatively low temperatures (less than $\sim 22{ }^{\circ} \mathrm{C}$ ) of 243 the liner surface (Fig. 2B and 2C). Associated voids represented by positive $\Delta \mathrm{T}$ were also 244 observed. Since the voids are mainly caused by gas expansion during hydrate dissociation, 245 which pushes the sediments apart, void intervals were included in pattern 2 as well.

\section{IR-temperature pattern 3: High gas concentration}

247 This temperature pattern was defined for core sections with relative moderate temperature 248 between 23 and $25{ }^{\circ} \mathrm{C}$, separated by distinct voids represented by slightly warmer 249 temperatures of $\sim 27{ }^{\circ} \mathrm{C}$. In some gas hydrate-free sediment intervals, cm-scaled voids 250 appeared in a dense pattern and revealed positive $\Delta \mathrm{T}$ in the IR images (e.g. $30.0-38.5$ 251 mbsf in core GMMB09; Fig. 3). Formation of voids is attributed to the expansion of 252 methane gas excluded from the dissolved phase due to depressurization.

\section{IR-temperature pattern 4: Intervals of unidentified liner content}


254 Large unfilled sections adjacent to gas hydrate-bearing sediment were occasionally 255 observed, for example in GMMB07 and GMMB11 (Fig. 3). However, it remained 256 unclear whether gas hydrates were present in these sections prior to IR imaging. Thus, we

257 defined these core sections as intervals of unidentified liner content.

\section{$258 \quad 4.2$ Pore water chloride concentrations}

259 Chloride concentrations in pore waters of $12 \mathrm{MeBo}$ cores were measured to study vertical 260 gas hydrate distributions and to compare the results with those obtained by IR thermal 261 scanning (Fig. 3). Chloride concentrations in bottom waters were around $550 \mathrm{mM}$ and 262 were also measured in near-surface sediments. With increasing depth, $\mathrm{Cl}^{-}$concentrations 263 showed a slightly decreasing trend in some cores such as GMMB08 and GMMB03. By 264 considering $\mathrm{Cl}^{-}=550 \mathrm{mM}$ as background, discrete positive and negative 265 concentrationanomalies were identified in the cores. Negative anomalies, with minimum 266 concentrations of $213.1 \mathrm{mM}$ at $38.83 \mathrm{mbsf}$ in core GMMB09, were found widely 267 distributed in gas hydrate-bearing sediments. These were caused by the dilution of pore 268 water by $\mathrm{Cl}^{-}$-free water which is released by hydrate dissociation during core recovery 269 (Torres et al., 2004a; Tréhu et al., 2004). Discrete positive $\mathrm{Cl}^{-}$anomalies, of up to 1059.7 $270 \mathrm{mM}$, in contrast are proposed to be associated with fast hydrate formation. During 271 formation of gas hydrates ions are excluded from the hydrate lattice, which results in an 272 increases in pore water chloride concentrations (Torres et al., 2011; Torres et al., 2004b). 273 In previous studies it was observed that for chloride back diffusion to background 274 concentrations takes a comparably long time (Haeckel et al., 2004). Therefore, positive 275 anomalies existing in situ can still be detected by conventional pore water analysis in case 
276 quick sampling prevents pore water dilution by fresh water from dissociating hydrates.

277 Since the pore water samples were taken immediately before the massive hydrates were

278 totally decomposed, the elevated chloride concentrations are a proxy for relatively recent

279 hydrate formation in sediments of the pockmarks.

\section{$280 \quad 4.3$ Regional and depth variations in gas hydrate distributions}

281 Both proxies, IR imaging and pore water chloride concentration profiling, revealed

282 similar gas hydrate down core distributions and only for some small intervals results from

283 both methods did not correlate (Table 1). Hydrates in pockmark A were present in the

284 central part at much shallower depth compared to the periphery (Fig. 3, Table 1).

285 Temperature anomalies captured by the IR images indicated that the top of the GHOZ in

286 the central part (GMMB06, GMMB07, GMMB08 and GMMB11) ranges from 2.3 mbsf

287 (GMMB08) to 6.5 mbsf (GMMB11), whereas chloride anomalies revealed hydrate

288 presence from $1.2 \mathrm{mbsf}$ (GMMB11) to $4.4 \mathrm{mbsf}$ (GMMB10). Peripheral cores

289 (GMMB03 and GMMB12) showed down core gas hydrate presence from 6.9 to $7.6 \mathrm{mbsf}$

290 by using IR imaging and 6.1 to 6.7 mbsf based on chloride anomalies (Fig. 3). These data

291 sets substantiate a very shallow top of the GHOZ in the pockmark center which deepens

292 towards its rim as already suggested by Sultan (2010). In core GMMB08, taken in the

293 NW central part of pockmark A, the down core gas hydrate distribution was indicated by

294 IR imaging down to 26.4 mbsf and by the chloride proxy down to $24.1 \mathrm{mbsf}$. In cores

295 GMMB03 and GMMB12 taken at the periphery of pockmark A, gas hydrate occurrences

296 were present from about 7 mbsf down to about 17 mbsf. 
297 In pockmarks $\mathrm{C} 1$ and $\mathrm{C} 2$, the top of the $\mathrm{GHOZ}$ was determined to be positioned between

2985.9 mbsf and 10.3 mbsf using IR imaging proxy, and $5.3 \mathrm{mbsf}$ and $8.5 \mathrm{mbsf}$ using

299 chloride anomalies (Fig. 3). Outside pockmark C2, core GMMB09 showed the deepest

300 gas hydrate occurrence of all MeBo cores from about 38.5 mbsf down to its maximum

301 penetration depth of 43.6 mbsf (Fig. 3).

\section{$302 \quad 4.4$ In situ sediment temperatures}

303 In situ temperature measurements conducted at ten stations in pockmark A using MTLs

304 showed slight variations in water temperatures ranging between 4.45 and $4.53{ }^{\circ} \mathrm{C}$ (Fig. 4 ,

305 Table 2). For the in situ sediment temperature measurements most geothermal gradients

306 showed linear or sub-linear slopes. The thermal gradient established at station GMGCT22,

307 which was performed outside pockmark A and is considered as reference station, was

308 about $72{ }^{\circ} \mathrm{C} / \mathrm{km}$. Similar thermal gradients ranging between 51 and $79{ }^{\circ} \mathrm{C} / \mathrm{km}$ were

309 determined for four other stations (GMGCT23, 24, 41 and 49). At a cluster of five

310 stations performed in the hummocky area elevated geothermal gradients were observed.

311 Slightly elevated gradients of 112 and $119^{\circ} \mathrm{C} / \mathrm{km}$ were measured at stations GMGCT46

312 and -47 , respectively. At stations GMGCT44, -45 and -40 , the gradients were 198 and

$313330{ }^{\circ} \mathrm{C} / \mathrm{km}$, which is 2.8 and 4.6 times higher than the gradient at the background station,

314 respectively. At station GMGCT40 a considerably elevated temperature deviating from

315 the general trend established by the other MTLs was measured with TL-2 at a sediment 316 depth of about 2 mbsf (Fig. 4). 


\section{5. Discussion}

\section{$318 \quad 5.1$ Thermal regime of pockmark A}

319 The geothermal gradient in the central part of pockmark A was significantly higher than

320 the local background gradient (Fig. 4). Elevated temperatures in marine sediments caused

321 by fluid flow have been widely reported from active mud volcanoes (e.g. Feseker et al.,

322 2008; 2009a;b; Foucher et al., 2010) and other marine seep types (Römer et al., 2012). At

323 pockmark A studied herein indications for mud flow activities such as mud breccia (Kopf,

324 2002) have not been found. However, free gas ebullition observed above the central part

325 of pockmark A during the expedition (for location see Sultan et al., 2014) proves fluid

326 upward migration at this structure. Thus, the temperature elevation in shallow sediment is

327 likely caused by fluid advection.

328 It is worth noting that none of our measured geothermal profiles is strictly linear. We

329 assume that besides the influence from heat convection induced by fluid flow,

330 precipitation of gas hydrates in pore space contributes partially to this phenomenon.

331 Several physical bulk sediment properties (i.e. thermal conductivity, heat capacity,

332 density) are altered by gas hydrate precipitation in the pore space. In particular, gas

333 hydrate formation is an exothermic reaction and heat is released when hydrate crystallizes

334 (Sloan and Koh, 2007; Waite et al., 2007). Waite et al. (2007) pointed out that the thermal

335 diffusivity of sediment with $60 \%$ porosity and $40 \%$ gas hydrate saturation increases by

$33620 \%$ compared to that of non-hydrate-bearing sediment. The gas hydrate saturation in the

337 studied pockmarks is not quantified yet. Nevertheless, we conservatively estimate that 338 gas hydrate saturations in specific sediment depths do not exceed $40 \%$ and that deviations 
339 of absolute temperatures caused by hydrates are $<20 \%$ with respect to a hypothetical

340 linear thermal gradient throughout the sediment.

341 At station GMGCT40 (Fig. 4) an exceptionally high temperature was measured with TL-

3422 if compared to the other temperature loggers mounted below and above. This

343 phenomenon was also observed at a high-flux seep area in the Black Sea (Römer et al.,

344 2012). Fig. 5 shows the continuous temperature change with time recorded with the

345 loggers during stations GMGCT40 and 41 when the corer has not been lifted out of the

346 water. It becomes obvious that at station GMGCT40 the absolute temperature measured

347 with TL-2 was generally highest and that the temperature slope reversed after a while.

348 Temperatures determined with TL-1, -3 , and -4 were lower and reached equilibrium in

349 contrast to that of TL-2. During station GMGCT41 absolute temperatures changed

350 according to the expected order which corresponded to the arrangement of loggers at the

351 gravity corer.

352 The temperature difference between TL- 1 and TL-2 is $0.127{ }^{\circ} \mathrm{C}$ which is two orders of

353 magnitude higher than the logger accuracy (see Table 2). Thus, we conclude that the

354 temperature measured with TL-2 was neither noise nor caused by wrong operation.

355 However, if we ignore the temperature measured with TL-2, temperatures determined

356 with the other three loggers show a linear regression with a slope similar to those of

357 GMGCT44 $\left(198^{\circ} \mathrm{C} / \mathrm{km}\right)$ and GMGCT45 $\left(258^{\circ} \mathrm{C} / \mathrm{km}\right)$ (see Fig. 4).

358 The exceptionally high temperature recorded at about 2 mbsf at station GMGCT40 can

359 not be explained by vertical fluid advection and/or sediment thermal properties changed

360 by hydrate formation. It is obvious that additional heat was generated at the depth 
361 between TL-1 and TL-3. In a 3D complex pockmark, spatially restricted temperature

362 elevations might be caused by lateral heat advection from fluid flow along fractures or

363 fast gas hydrate formation. Gas hydrate formation and dissociation are exothermic and

364 endothermic processes, respectively, which subsequently change the thermal regime of

365 pockmarks (Chen and Cathles, 2005). During the cruise, gas hydrate with bubble fabric,

366 which is an indication of fast gas hydrate crystallization from methane bubbles

367 (Bohrmann et al., 1998), was sampled with gravity cores. Since gas hydrate occurs

368 widely in the center of pockmark A, its crystallization could release significant amounts

369 of heat (Chen and Cathles, 2005). Although we did not further investigate the amount of

370 freshly formed hydrate required to induce the relative temperature increase observed, we

371 speculate that TL-2 might have intersected with a fracture in which either gas hydrate

372 precipitated rapidly and/or fluid flowed happened facilitating lateral heat convection.

373 Because gas hydrates are sensitive to temperature variations (e.g. Feseker et al., 2009b;

374 Pape et al., 2011; Römer et al., 2012; Berndt et al., 2014) thermal variations in the

375 sediment impact gas hydrate distributions. At active seeps, temperature elevation in

376 shallow sediments due to fluid advection lift the base of the GHSZ (e.g. Ginsburg et al.,

377 1999; Römer et al., 2012). Considering the maximum $\left(258{ }^{\circ} \mathrm{C} / \mathrm{km}\right)$ and minimum

$378\left(72^{\circ} \mathrm{C} / \mathrm{km}\right)$ geothermal gradients determined in this study (Table 2), the base of the

379 GHSZ under pockmark A should be situated between $35 \mathrm{mbsf}$ and $130 \mathrm{mbsf}$, respectively

380 (Fig. 6). Since high thermal gradients were detected only in a restricted area NW of the

381 geometrical center of the pockmark, we assume that distinct temperature elevations

382 caused by fluid advection influence the GHSZ only on a small scale. In the water column, 
383 the top of the GHSZ is estimated to be at $587 \mathrm{mbsl}$ which is consistent with the maximum

384 height of gas flares observed above pockmark A during the cruise (Sultan et al., 2014).

\section{$385 \quad 5.2$ Gas hydrate and fluid flow}

386 Results from IR scanning and pore water chloride concentration analysis of the MeBo

387 cores as well as recoveries substantiate gas hydrate presence in shallow (meters to tens of

388 meters depth) sediments of the three studied pockmarks. It was shown that shallow gas

389 hydrates at active marine seeps primarily form from free gas (Haeckel et al., 2004; Römer

390 et al., 2012; Sahling et al., 2008; Torres et al., 2004b; Wallmann et al., 2006). Gas flares

391 observed above pockmark A during the survey in 2011 are direct evidence of gas flow

392 through the sediment (Sultan et al., 2014). Therefore, we assume that gas hydrates in the

393 studied pockmarks are mainly formed from the free gas phase. Free gas captured in

394 pockets within the GHOZ might contribute to the high amplitude reflectors observed in

395 seismic records from that area (Figs .7). In particular, at station GMMB04 in pockmark

396 C1 showed vigorous gas expulsion during drilling at $\sim 18 \mathrm{mbsf}$, which corresponds to

397 distinct high amplitude reflectors (Fig. 7B) (Sultan et al., 2014).

398 Free gas can migrate along fractures and gas hydrate can precipitate along fracture walls

399 (Torres et al., 2004b; Flemings et al., 2003) where fluid pressure and crystallization

400 forces are less than the effective overburden stress. In case free methane-rich gas

401 migrates upward into shallow sediment, where fluid pressure and crystallization force

402 exceed the effective overburden stress, it spreads out in the pore space and reacts with

403 water, forming gas hydrate (Torres et al., 2004b). This assumption is supported by our

404 observation of gas hydrates present within the upper $\sim 30 \mathrm{~m}$ (Figs. 2, 3, 7). Because the 
405 maximum depth of the GHSZ at pockmark A is situated at around 130 mbsf (geothermal 406 gradient: $72{ }^{\circ} \mathrm{C} / \mathrm{km}$; Table 2; Fig. 6), we might assume that gas hydrate also forms at 407 greater depth.

408 However, gas flow in a seep system is not under steady state (Bangs et al., 2011; Chand 409 et al., 2012; Gay et al., 2006b; Greinert et al., 2006) and pressure drop in deep gas 410 reservoirs (Bangs et al., 2011) and/or sealing of pathways by gas hydrate formation 411 (Riedel et al., 2006) might result in a decrease, or even cease of gas flow. Thus, although 412 no gas flares were recognized at pockmark $\mathrm{C} 1$ and $\mathrm{C} 2$ during this expedition, gas 413 hydrates in these two pockmarks likely formed from active gas flow in the recent past.

414 Upward gas migration stimulates the anaerobic methane oxidation (AOM) mediated by 415 methanotrophic archaea and sulfate reducing bacteria in near-surface sediments (Hoehler 416 et al., 1994; Boetius et al., 2000), and the resulting end products, such as hydrogen sulfide, 417 nourish a chemosynthesis-based ecosystem (Sahling et al., 2008). During our expedition 418 living vesicomyid clams, which rely on sulfide oxidation, were recovered from the 419 seafloor in the studied area, indicating a living chemosynthetic ecosystem. However, as 420 mentioned above, gas flow at a seep system is a transient process. Bangs et al. (2011) 421 pointed out that methane gas flow for a vent at Southern Hydrate Ridge has undergone 422 significant reduction or complete interruption within just a few years, whereas the 423 associated ecosystem has persisted for thousands of years. This observation raises the 424 question, how the chemosynthesis-based species survive during periods of reduced gas 425 flow. In a gas hydrate setting methane diffuses continuously from the shallow gas hydrate 426 reservoir towards the methane-depleted sea water and sustains AOM. This is consistent 
427 with the assumption of Sultan et al. (2010) that many gas hydrate reservoirs in the study 428 area are currently undergoing dissolution due to insufficient methane supply from greater 429 depth. Similar conclusions of chemosynthetic-based macrofauna presumably relying on 430 continuous methane supply from decomposing hydrates were already proposed for seep 431 systems in other regions (e.g., Paull et al., 1995; Pape et al., 2014). Thus, we propose that 432 gas hydrate reservoirs in shallow sediments serve as a capacitor (see e.g. Dickens, 2003), 433 as they form rapidly during a high gas-flow phase, and sustain the seep ecosystem by

434 slow methane diffusion when the gas flow from below is reduced.

\section{$435 \quad 5.3$ Pockmark formation}

436 It was initially proposed by Sultan et al. (2010) that gas hydrate dissolution caused by 437 insufficient gas supply is the controlling factor for pockmark formation and evolution in 438 the study area. New field data suggested that pockmark formation is not only controlled 439 by slow gas hydrate dissolution but also by rapid hydrate formation (Sultan et al., 2014).

440 Based on the data obtained from the MeBo cores in this study, an improved but simple 441 model comprising five stages is suggested for the evolution of the pockmarks (Fig. 8) in 442 the studied area

443 Stage A: Gas migrates from a deep source. Within the GHSZ, when the hydrate 444 crystallization force overcomes the burden of the overlying sediment, gas hydrate starts 445 precipitating in the shallow sediment. Gas hydrate growth decreases the pore space 446 availability and sediment permeability and clogs the pathways of fluid flow, which 447 subsequently decreases or even ceases the fluid flow in uppermost sediments. During this 
448 stage, there is neither a distinct morphological change on the seafloor nor gas emission

449 into the water column.

450 Stage B: In case of reduced gas flow to shallow sediments, sulfate can penetrate to 451 greater depths, which leads to a downward shift of the SMI (see e.g. Borowski et al., 452 1996). Methane in the shallow sediment is likely depleted due to diffusion and AOM. As 453 a result, gas hydrates dissolve from the top of the GHOZ (see Sultan et al., 2010). 454 Subsequently, the overlying sediment is deformed due to the volume loss below and a 455 seafloor depression is created. This stage might explain the $\sim 2 \mathrm{~m}$ depression observed for 456 pockmark C2 (Figs. 1 and 7).

457 Stage C: Once the fluid flow is re-intensified, methane and shallow hydrate repeat the 458 same procedure as described in Stage A. When pore pressure surpasses a threshold value, 459 fractures are generated in the overlying sediment at the pockmark center (e.g. observed in 460 pockmark A, Fig. 7) which might serve as pathways for free gas to migrate to the seafloor. 461 Since these fractures form within the GHSZ, gas hydrates might accumulate along the 462 fracture walls which efficiently prevents the contact between pore water and gases. Fast 463 gas hydrate formation will significantly increase the salinity of the surrounding pore 464 water due to ion exclusion and the resulting brine might locally prevent gas hydrate 465 formation (Ussler \& Paull, 1995; Torres et al., 2011). Massive gas hydrate accumulating 466 in the shallow sediment expands the mass volume and creates convex-shaped elevations 467 as well as a rough seafloor, like observed close to the center of pockmark A (Fig. 1). This 468 can explain the cones and hummocky structure at the centers of pockmarks A and C1 (Fig. $4697)$. 
470 Stage D: In case the methane flux is redirected towards shallow sediments in the vicinity

471 of the initial pockmark, a new pockmark might be created and might repeat stages A-C.

472 Stage E: The complexity and size of a pockmark might increase significantly in case

473 more and more new pockmarks morphologically combine (Marcon et al., 2014). It might

474 be assumed that pockmark C1, which exhibits a roughly NE-SW seafloor expression and

475 complex seafloor morphology, is composed of several small pockmarks at different 476 stages.

\section{6. Conclusion}

478 Gas hydrate distributions in the sediment of three pockmarks on the Nigerian continental 479 margin were investigated by applying infrared (IR) thermal imaging and pore water 480 chloride and sulfate concentration measurements on cores recovered with the portable 481 MeBo drill rig. In addition, ten in situ sediment temperature measurements were 482 performed to study the geothermal regime of the individual pockmark A. Based on the 483 temperature and chloride anomalies, the following conclusions are drawn:

484 1. Negative temperature anomalies detected by IR thermal scanning as well as positive 485 and negative chloride anomalies in pore waters indicated the presence of gas hydrate in 486 shallow pockmark sediments. Distributions of gas hydrate-bearing sediments as inferred 487 from both methods match each other.

488 2. Geothermal gradients up to 5 times higher in the center of pockmark A than the 489 background were interpreted to result from enhanced heat advection caused in the course 490 of fluid flow and potentially also to fast growth of gas hydrates. 
491 3. Recent hydrate formation is inferred from positive chloride anomalies.

492 4. Gas hydrate precipitation and dissolution caused by the variation of fluid flow exert

493 significant impact on the formation and evolution of pockmarks on the Nigerian 494 continental margin.

495 


\section{Acknowledgement}

498 We thank the captain and crew of $R / V$ Pourquoi pas? for support during the Guineco-

499 MeBo cruise in 2011. We thank also the MeBo team from MARUM and the staff of

500 IFREMER for the excellent help during the cruise. We are thankful for the constructive

501 comments from C. Berndt and an anonymous reviewer which helped to improve the 502 manuscript significantly.

503 This work was partly funded through the DFG-Research Center/Excellence Cluster "The

504 Ocean in the Earth System" MARUM - Center for Marine Environmental Sciences. A 505 major financial contribution came from BMBF-project 03G0824A.

506 Data used in the present paper are covered by a confidentiality agreement between Total, 507 IFREMER and MARUM that restrict access; interested readers can contact the authors 508 for more information. J. Wei was sponsored by the China Scholarship Council (CSC). 
511

Abegg, F., Bohrmann, G., Freitag, J., and Kuhs, W., 2007, Fabric of gas hydrate in sediments from Hydrate Ridge_results from ODP Leg 204 samples: Geo-Marine Letters, v. 27, no. 2-4, p. 269-277.

Andresen, K. J., Huuse, M., and Clausen, O. R., 2008, Morphology and distribution of Oligocene and Miocene pockmarks in the Danish North Sea - implications for bottom current: Basin Research, v. 20, no. 3, p. 445-466.

Bangs, N. L. B., Hornbach, M. J., and Berndt, C., 2011, The mechanics of intermittent methane venting at South Hydrate Ridge inferred from 4D seismic surveying: Earth and Planetary Science Letters, v. 310, no. $1-2$, p. $105-112$.

Bayon, G., Pierre, C., Etoubleau, J., Voisset, M., Cauquil, E., Marsset, T., Sultan, N., Le Drezen, E., and Fouquet, Y., 2007, $\mathrm{Sr} / \mathrm{Ca}$ and $\mathrm{Mg} / \mathrm{Ca}$ ratios in Niger Delta sediments: Implications for authigenic carbonate genesis in cold seep environments: Marine Geology, v. 241, no. 1-4, p. 93-109.

Berndt, C., Feseker, T., Treude, T., Krastel, S., Liebetrau, V., Niemann, H., Bertics, V. J., Dumke, I., Dünnbier, K., Ferré, B., Graves, C., Gross, F., Hissmann, K., Hühnerbach, V., Krause, S., Lieser, K., Schauer, J., and Steinle, L., 2014, Temporal Constraints on Hydrate-Controlled Methane Seepage off Svalbard: Science, v. 343, no. 6168, p. 284-287.

Boetius, A., Ravenschlag, K., Schubert, C. J., Rickert, D., Widdel, F., Gieseke, A., Amann, R., Jorgensen, B. B., Witte, U., and Pfannkuche, O., 2000, A marine microbial consortium apparently mediating anaerobic oxidation of methane: Nature, v. 407, no. 6804, p. 623-626.

Bohrmann, G., Greinert, J., Suess, E., and Torres, M., 1998, Authigenic carbonates from the Cascadia subduction zone and their relation to gas hydrate stability: Geology, v. 26, no. 7, p. 647-650.

Borowski, W.S., Paull, C.K., Ussler III, W., (1996) Marine pore-water sulfate profiles indicate in situ methane flux from underlying gas hydrate. Geology, 24(7), 655-658. 
533

534

535

536

Brooks, J. M., Bryant, W. R., Bernard, B. B., and Cameron, N. R., 2000, The Nature of Gas Hydrates on the Nigerian Continental Slope: Annals of the New York Academy of Sciences, v. 912, no. 1, p. 76-93.

Bünz, S., Mienert, J., and Berndt, C., 2003, Geological controls on the Storegga gas-hydrate system of the mid-Norwegian continental margin: Earth and Planetary Science Letters, v. 209, no. 3-4, p. 291307.

Carson, B., Seke, E., Paskevich, V., Holmes, M.L., (1994) Fluid expulsion sites on the Cascadia accretionary prism: Mapping diagenetic deposits with processed GLORIA imagery. J. Geophys. Res., 99(B6), 11959-11969.

Chand, S., Thorsnes, T., Rise, L., Brunstad, H., Stoddart, D., Bøe, R., Lågstad, P., and Svolsbru, T., 2012, Multiple episodes of fluid flow in the SW Barents Sea (Loppa High) evidenced by gas flares, pockmarks and gas hydrate accumulation: Earth and Planetary Science Letters, v. 331-332, no. 0, p. $305-314$

Chen, D. F., and Cathles, L. M., 2005, On the thermal impact of gas venting and hydrate crystallization: Journal of Geophysical Research: Solid Earth, v. 110, no. B11, p. B11204.

Chen, S.-C., Hsu, S.-K., Tsai, C.-H., Ku, C.-Y., Yeh, Y.-C., and Wang, Y., 2010, Gas seepage, pockmarks and mud volcanoes in the near shore of SW Taiwan: Marine Geophysical Researches, v. 31, no. 12, p. 133-147.

Cohen, H. A., and McClay, K., 1996, Sedimentation and shale tectonics of the northwestern Niger Delta front: Marine and Petroleum Geology, v. 13, no. 3, p. 313-328.

Cunningham, R., and Lindholm, R. M., 2000, AAPG Memoir 73, Chapter 8: Seismic Evidence for Widespread Gas Hydrate Formation, Offshore West Africa.Damuth, J. E., 1994, Neogene gravity tectonics and depositional processes on the deep Niger Delta continental margin: Marine and Petroleum Geology, v. 11, no. 3, p. 320-346. 
557 Dickens, G.R., (2003) Rethinking the global carbon cycle with a large, dynamic and microbially mediated gas hydrate capacitor. Earth and Planetary Science Letters, 213(3-4), 169-183.

Dondurur, D., Çifçi, G., Drahor, M. G., and Coşkun, S., 2011, Acoustic evidence of shallow gas accumulations and active pockmarks in the Izmir Gulf, Aegean sea: Marine and Petroleum Geology, v. 28, no. 8, p. 1505-1516.

Feseker, T., Dählmann, A., Foucher, J. P., and Harmegnies, F., 2009a, In-situ sediment temperature measurements and geochemical porewater data suggest highly dynamic fluid flow at Isis mud volcano, eastern Mediterranean Sea: Marine Geology, v. 261, no. 1-4, p. 128-137.

Feseker, T., Foucher, J. P., and Harmegnies, F., 2008, Fluid flow or mud eruptions? Sediment temperature distributions on Håkon Mosby mud volcano, SW Barents Sea slope: Marine Geology, v. 247, no. 3-4, p. 194-207.

Feseker, T., Pape, T., Wallmann, K., Klapp, S.A., Schmidt-Schierhorn, F., Bohrmann, G., (2009b) The thermal structure of the Dvurechenskii mud volcano and its implications for gas hydrate stability and eruption dynamics. Marine and Petroleum Geology, 26(9), 1812-1823.

Flemings, P. B., Liu, X., and Winters, W. J., 2003, Critical pressure and multiphase flow in Blake Ridge gas hydrates: Geology, v. 31, no. 12, p. 1057-1060. seabed morphology, mud temperature and free gas venting at the Håkon Mosby mud volcano, offshore northern Norway, over the time period 2003-2006: Geo-Marine Letters, v. 30, no. 3-4, p. $157-167$. drilling rig MeBo: Geosci. Instrum. Method. Data Syst. Discuss., v. 3, no. 2, p. 347-369. 
Gay, A., Lopez, M., Cochonat, P., Levaché, D., Sermondadaz, G., and Seranne, M., 2006a, Evidences of early to late fluid migration from an upper Miocene turbiditic channel revealed by 3D seismic coupled to geochemical sampling within seafloor pockmarks, Lower Congo Basin: Marine and Petroleum Geology, v. 23, no. 3, p. 387-399.

Gay, A., Lopez, M., Ondreas, H., Charlou, J. L., Sermondadaz, G., and Cochonat, P., 2006b, Seafloor facies related to upward methane flux within a Giant Pockmark of the Lower Congo Basin: Marine Geology, v. 226, no. 1-2, p. 81-95.

George, R. A., and Cauquil, E., AUV Ultrahigh-Resolution 3D Seismic Technique for Detailed Subsurface Investigations, in Proceedings Offshore Technology Conference2007, Offshore Technology Conference.

Ginsburg, G. D., Milkov, A. V., Soloviev, V. A., Egorov, A. V., Cherkashev, G. A., Vogt, P. R., Crane, K., Lorenson, T. D., and Khutorskoy, M. D., 1999, Gas hydrate accumulation at the Håkon Mosby Mud Volcano: Geo-Marine Letters, v. 19, no. 1-2, p. 57-67.

Graue, K., 2000, Mud volcanoes in deepwater Nigeria: Marine and Petroleum Geology, v. 17, no. 8, p. 959974.

Greinert, J., Artemov, Y., Egorov, V., De Batist, M., and McGinnis, D., 2006, 1300-m-high rising bubbles from mud volcanoes at $2080 \mathrm{~m}$ in the Black Sea: Hydroacoustic characteristics and temporal variability: Earth and Planetary Science Letters, v. 244, no. 1-2, p. 1-15.

Haeckel, M., Suess, E., Wallmann, K., and Rickert, D., 2004, Rising methane gas bubbles form massive hydrate layers at the seafloor: Geochimica et Cosmochimica Acta, v. 68, no. 21, p. 4335-4345.

Hartwig, A., Anka, Z., and di Primio, R., 2012, Evidence of a widespread paleo-pockmarked field in the Orange Basin: An indication of an early Eocene massive fluid escape event offshore South Africa: Marine Geology, v. 332-334, p. 222-234. 
602 Heggland, R., Vertical hydrocarbon migration at the Nigerian continental slope: applications of seismic mapping techniques, in Proceedings AAPG Annual Meeting, Salt Lake City, May2003, p. 11-14.

604 Hoehler, T.M., Alperin, M.J., Albert, D.B., Martens, C.S., (1994) Field and laboratory studies of methane oxidation in an anoxic marine sediment: Evidence for a methanogen-sulfate reducer consortium. Global Biogeochemical Cycles, 8(4), 451-463.

Hovland, M., Gallagher, J. W., Clennell, M. B., and Lekvam, K., 1997, Gas hydrate and free gas volumes in marine sediments: Example from the Niger Delta front: Marine and Petroleum Geology, v. 14, no. 3, p. 245-255.

Judd, A. A. G., and Hovland, M., 2007, Seabed fluid flow: the impact of geology, biology and the marine environment, Cambridge University Press.

612 Kopf, A. J., 2002, Significance of mud volcanism: Reviews of Geophysics, v. 40, no. 2, p. 1005.

613 Marcon, Y., Ondréas, H., Sahling, H., Bohrmann, G., and Olu, K., 2014, Fluid flow regimes and growth of a giant pockmark: Geology, v. 42, no. 1, p. 63-66.

615 Masoudi, R., Tohidi, B., (2005) Estimating the hydrate stability zone in the presence of salts and/or organic inhibitors using water partial pressure. Journal of Petroleum Science and Engineering, 46(1-2), 2336.

618 Matsumoto, R., Ryu, B.-J., Lee, S.-R., Lin, S., Wu, S., Sain, K., Pecher, I., and Riedel, M., 2011, Occurrence and exploration of gas hydrate in the marginal seas and continental margin of the Asia and Oceania region: Marine and Petroleum Geology, v. 28, no. 10, p. 1751-1767. 
623 Pape, T., Feseker, T., Kasten, S., Fischer, D., Bohrmann, G., (2011) Distribution and abundance of gas hydrates in near-surface deposits of the Håkon Mosby Mud Volcano, SW Barents Sea. Geochemistry, Geophysics, Geosystems, 12(9), Q09009.

Pape, T., Geprägs, P., Hammerschmidt, S., Wintersteller, P., Wei, J., Fleischmann, T., Bohrmann, G., Kopf, A.J., (2014) Hydrocarbon seepage and its sources at mud volcanoes of the Kumano forearc basin, Nankai Trough subduction zone. Geochemistry, Geophysics, Geosystems, 15(6), 2180-2194.

Paull, C.K., Ussler III, W., Borowski, W.S., Spiess, F.N., (1995) Methane-rich plumes on the Carolina continental rise: Associations with gas hydrates. Geology, 23(1), 89-92.

Paull, C. K., Ussler, W., Holbrook, W. S., Hill, T. M., Keaten, R., Mienert, J., Haflidason, H., Johnson, J. E., Winters, W. J., and Lorenson, T. D., 2008, Origin of pockmarks and chimney structures on the flanks of the Storegga Slide, offshore Norway: Geo-Marine Letters, v. 28, no. 1, p. 43-51.

634 Pilcher, R., and Argent, J., 2007, Mega-pockmarks and linear pockmark trains on the West African continental margin: Marine Geology, v. 244, no. 1-4, p. 15-32.

Pinet, N., Duchesne, M., and Lavoie, D., 2010, Linking a linear pockmark train with a buried Palaeozoic structure: a case study from the St. Lawrence Estuary: Geo-Marine Letters, v. 30, no. 5, p. 517-522.

Riboulot, V., Cattaneo, A., Sultan, N., Garziglia, S., Ker, S., Imbert, P., and Voisset, M., 2013, Sea-level change and free gas occurrence influencing a submarine landslide and pockmark formation and distribution in deepwater Nigeria: Earth and Planetary Science Letters, v. In Press, Corrected Proof.

Riedel, M., Novosel, I., Spence, G. D., Hyndman, R. D., Chapman, R. N., Solem, R. C., and Lewis, T., 2006, Geophysical and geochemical signatures associated with gas hydrate-related venting in the

644 northern Cascadia margin: Geological Society of America Bulletin, v. 118, no. 1-2, p. 23-38. 
645 Rise, L., Sættem, J., Fanavoll, S., Thorsnes, T., Ottesen, D., and Bøe, R., 1999, Sea-bed pockmarks related to fluid migration from Mesozoic bedrock strata in the Skagerrak offshore Norway: Marine and Petroleum Geology, v. 16, no. 7, p. 619-631.

Ritger, S., Carson, B., Suess, E., (1987) Methane-derived authigenic carbonates formed by subductioninduced pore-water expulsion along the Oregon/Washington margin. Geological Society of America Bulletin, 98, 147-156.

Römer, M., Sahling, H., Pape, T., Bahr, A., Feseker, T., Wintersteller, P., and Bohrmann, G., 2012, Geological control and magnitude of methane ebullition from a high-flux seep area in the Black Sea-the Kerch seep area: Marine Geology, v. 319-322, no. 0, p. 57-74.

Sahling, H., Bohrmann, G., Spiess, V., Bialas, J., Breitzke, M., Ivanov, M., Kasten, S., Krastel, S., and Schneider, R., 2008, Pockmarks in the Northern Congo Fan area, SW Africa: Complex seafloor features shaped by fluid flow: Marine Geology, v. 249, no. 3-4, p. 206-225.

Seeberg-Elverfeldt, J., Schlüter, M., Feseker, T., Kölling, M., (2005) Rhizon sampling of porewaters near the sediment-water interface of aquatic systems. Limnology and Oceanography: Methods, 3, 361371.

Sloan, E. D., and Koh, C., 2007, Clathrate hydrates of natural gases, CRC press.

Sultan, N., Bohrmann, G., Ruffine, L., Pape, T., Riboulot, V., Colliat, J. L., De Prunelé, A., Dennielou, B., Garziglia, S., Himmler, T., Marsset, T., Peters, C. A., Rabiu, A., and Wei, J., 2014, Pockmark formation and evolution in deep water Nigeria: Rapid hydrate growth versus slow hydrate dissolution: Journal of Geophysical Research: Solid Earth, v. 119, no. 4, p. 2013 JB010546.

Sultan, N., Marsset, B., Ker, S., Marsset, T., Voisset, M., Vernant, A.-M., Bayon, G., Cauquil, E., Adamy, J., and Colliat, J., 2010, Hydrate dissolution as a potential mechanism for pockmark formation in the Niger delta: Journal of geophysical research, v. 115, no. B8, p. B08101. 
668 Sun, Q., Wu, S., Hovland, M., Luo, P., Lu, Y., and Qu, T., 2011, The morphologies and genesis of megapockmarks near the Xisha Uplift, South China Sea: Marine and Petroleum Geology, v. 28, no. 6, p. $1146-1156$.

Torres, M. E., Kim, J.-H., Choi, J.-Y., Ryu, B.-J., Bahk, J.-J., Riedel, M., Collett, T. S., Hong, W.-L., and Kastner, M., Occurrence of high salinity fluids associated with massive near-seafloor gas hydrate deposits, in Proceedings 7th International Conference on Gas Hydrates (ICGH 2011)2011.

674 Torres, M. E., Teichert, B. M. A., Tréhu, A. M., Borowski, W., and Tomaru, H., 2004a, Relationship of pore water freshening to accretionary processes in the Cascadia margin: Fluid sources and gas hydrate growth, methane transport, and chloride enrichment at the southern summit of Hydrate Ridge, Cascadia margin off Oregon: Earth and Planetary Science Letters, v. 226, no. 1-2, p. 225241.

Tréhu, A. M., Long, P. E., Torres, M. E., Bohrmann, G., Rack, F. R., Collett, T. S., Goldberg, D. S., Milkov, A. V., Riedel, M., Schultheiss, P., Bangs, N. L., Barr, S. R., Borowski, W. S., Claypool, G. E., Delwiche, M. E., Dickens, G. R., Gracia, E., Guerin, G., Holland, M., Johnson, J. E., Lee, Y. J.,

Ussler III, W., Paull, C.K., (1995) Effects of ion exclusion and isotopic fractionation on pore water geochemistry during gas hydrate formation and decomposition. Geo-Marine Letters, 15(1), 37-44. a case study from Belfast Bay, Maine: Marine Geology, v. 202, no. 3-4, p. 175-192. 
691 Waite, W. F., Stern, L. A., Kirby, S. H., Winters, W. J., and Mason, D. H., 2007, Simultaneous 692 determination of thermal conductivity, thermal diffusivity and specific heat in sI methane hydrate: Geophysical Journal International, v. 169, no. 2, p. 767-774.

694 Wallmann, K., Aloisi, G., Haeckel, M., Obzhirov, A., Pavlova, G., and Tishchenko, P., 2006, Kinetics of 695 organic matter degradation, microbial methane generation, and gas hydrate formation in anoxic marine sediments: Geochimica et Cosmochimica Acta, v. 70, no. 15, p. 3905-3927.

697 Weinberger, J. L., Brown, K. M., and Long, P. E., 2005, Painting a picture of gas hydrate distribution with thermal images: Geophysical Research Letters, v. 32, no. 4, p. L04609.

699 


\section{Figure captions:}

703 Figure 1: (A): Location of the pockmark field at the Nigerian continental margin. (B): Overview 704 of the studied pockmark field. (C) and (D): MeBo drill sites (GMMB) in pockmarks A and C (C1 705 and C2), respectively. Numbers refer to individual MeBo station codes (i.e. No. $01=$ station

706 GMMB01, for example) Track lines of SYSIF seismic profiles SY03-THR-Pr01 and SY01-HR-

707 Pr02 as well as the shot points are shown. For exact positions refer to Sultan et al. (2014).

708 Figure 2: Combined illustration of core photographs (left) and IR images (right) of the $6.6 \mathrm{~m}$-long

709 MeBo drill core GMMB06. Representative intervals of the core (A, B and C) are shown in detail

710 (right part of the figure). (A): normal hemi-pelagic sediment (upper part) and voids (lower part),

711 which in the IR images correspond to the background temperature (orange) and high temperature

712 (yellow), respectively. The bright spot (white) is an artifact generated during the core handling.

713 (B): Moussy sediment with cracks, which in the IR image shows three cold temperature zones

714 (light purple) caused by the dissociation of disseminated gas hydrates. (C): Soupy and fluidized

715 sediments. The cold temperature interval below 5.70 mbsf contained gas hydrates including a 716 nodular gas hydrate between 5.80 and 5.85 mbsf represented by an extremely cold spot (dark

717 purple to black). $\mathrm{GH}=$ gas hydrate

718 Figure 3: IR temperatures and pore water chloride concentration profiles of MeBo cores. Four 719 data sets are shown for most drill sites: IR image colors, IR temperature profiles, interpreted gas 720 hydrate distributions, and chloride profiles. The color bar of the IR images is consistent with Fig. 7212 and white intervals indicate gaps. Temperature profiles show the differences between the 722 measured temperature and background temperatures of core liners, expressed as $\Delta \mathrm{T}$. Positive $\Delta \mathrm{T}$ 723 values correlate with voids in the cores and negative $\Delta \mathrm{T}$ values represent decomposing gas 724 hydrates. The approximate down-core gas hydrate presence interpreted from IR images is 
725 indicated by colored bars and indications for depth below seafloor (mbsf). Depths of gas hydrate-

726 bearing intervals as inferred from chloride anomalies are highlighted in blue shading. Note that

727 the chloride data of the upper 12.7 mbsf at station GMMB09 were derived from a piston core

728 (GMCS10) taken at the same position.

729 Figure 4: A: Position of sites chosen for temperature measurements in pockmark A. B: In situ

730 sediment temperature measurements. Temperature gradients were classified into two clusters: (1)

731 background gradients (around $72{ }^{\circ} \mathrm{C} / \mathrm{km}$ ) highlighted by the dark grey background, and (2) high

732 gradients caused by fluid advection without background color.

733 Figure 5: Temperature change with time at stations GMGCT40 and GMGCT41. TL-1 to TL-5

734 represents the temperature sensors attached to the corer from base to top. Remarkably, the

735 temperature measured with TL-2 at station GMGCT40 increased continuously after penetration

736 and was higher than that of TL-1, which penetrated deeper into the sediment. Note that TL-5 had

737 no contact with sediment and, therefore, measured bottom water temperature.

738 Figure 6: Phase diagram calculated for structure I gas hydrates with the HWHYD software

739 (Masoudi and Tohidi, 2005) and using salinities and pure methane because methane concentration

740 of hydrate-bounded gas is higher than $99.9 \%$ (unpublished data). A CTD record was used to show

741 the water column temperature profile. $72{ }^{\circ} \mathrm{C} / \mathrm{km}$ (GMGCT22) was used as the local background

742 geothermal gradient outside the pockmarks, while $258^{\circ} \mathrm{C} / \mathrm{km}$ (GMGCT45) was measured close

743 to a site at pockmark center which showed seafloor gas emission (see Sultan et al., 2014). The

744 subsurface part (dash blue rectangle) of the diagram is enlarged in the right part of the figure.

745 Figure 7: SYSIF seismic profiles SY03-THR-Pr01 crossing pockmark A and SY01-THR-Pr02

746 covering pockmark cluster C. Locations and orientations are shown in Fig. 1. Interpretations from

747 MeBo cores are projected on the seismic lines. High-amplitude reflectors are widespread in the 748 seismic profile. 
749 Figure 8: Schematic representations of the pockmark formation controlled by fluid flow and gas

750 hydrate precipitation during different evolutionary stages (A-E).

751 
2 Table 1: Basic information of the MeBo cores taken during the Guienco-MeBo cruise as well as

3 upper and lower boundaries of the gas hydrate occurrence zone (GHOZ) estimated using IR

4 thermal scanning and pore water chloride concentration anomalies, respectively. mbsl: meters

5 below sea level. mbsf: meters below seafloor. nd: not detected. nc: not calculated.

6

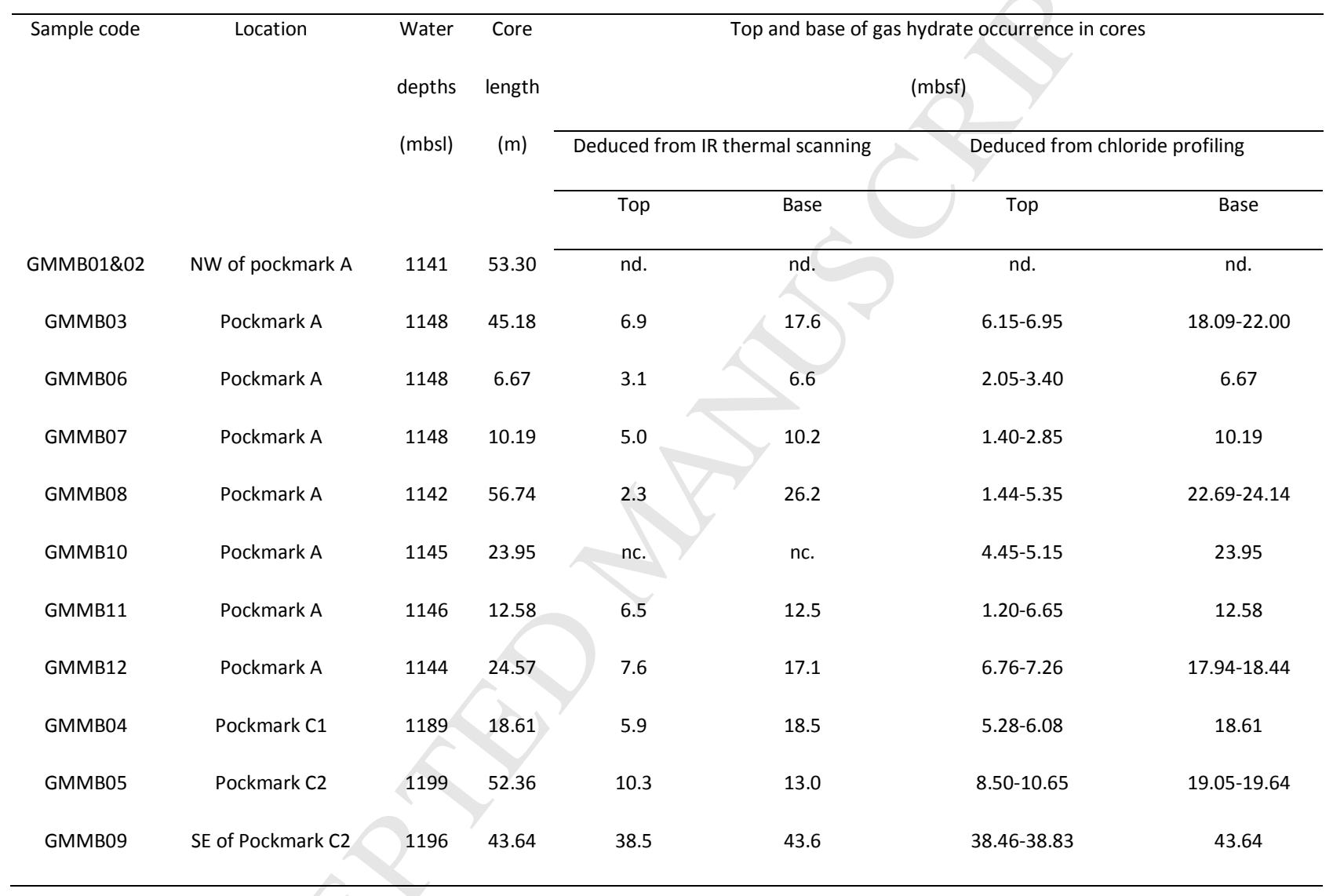


2 Table 2: Stations of in situ sediment temperature measurements in pockmark A with temperatures 3 probes (GMGCT) during the Guineco-MeBo cruise. For calculation of STD, water temperatures 4 measured $50 \mathrm{~m}$ above seafloor with the MTLs at individual stations were used. *Note: because of 5 the non-linear slope of the profile this gradient was not considered further

6 n: number of probes from which geothermal gradients were calculated.

\begin{tabular}{cccccc}
\hline & Water depth & Water temperature & STD & Thermal gradients & $\mathrm{n}$ \\
& $(\mathrm{m})$ & $\left({ }^{\circ} \mathrm{C}\right)$ & $\left({ }^{\circ} \mathrm{C}\right)$ & $\left({ }^{\circ} \mathrm{C} / \mathrm{km}\right)$ & \\
\hline GMGCT22 & 1144 & 4.53 & 0.006 & 72 & 5 \\
GMGCT23 & 1142 & 4.52 & 0.005 & 79 & 5 \\
GMGCT24 & 1143 & 4.52 & 0.005 & 70 & 5 \\
GMGCT40 & 1144 & 4.46 & 0.005 & $330^{*}$ & 4 \\
GMGCT41 & 1143 & 4.46 & 0.005 & 73 & 4 \\
GMGCT44 & 1140 & 4.46 & 0.005 & 198 & 4 \\
GMGCT45 & 1141 & 4.45 & 0.004 & 258 & 4 \\
GMGCT46 & 1140 & 4.46 & 0.008 & 112 & 4 \\
GMGCT47 & 1141 & 4.46 & 0.006 & 119 & 2 \\
GMGCT49 & 1142 & 4.45 & 0.007 & 51 & 4 \\
\hline
\end{tabular}




\section{ACCEPTED MANUSCRIPT}
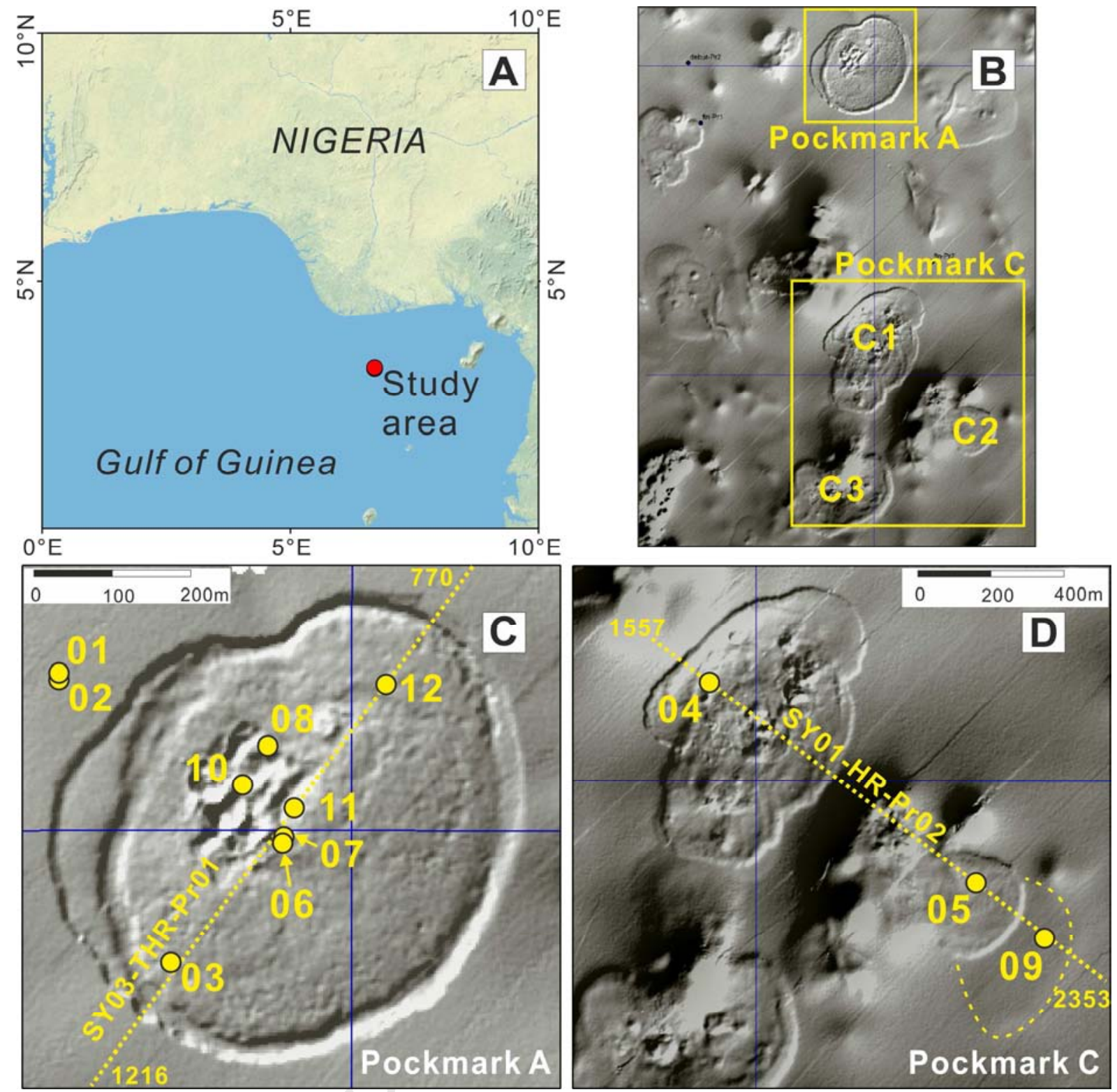

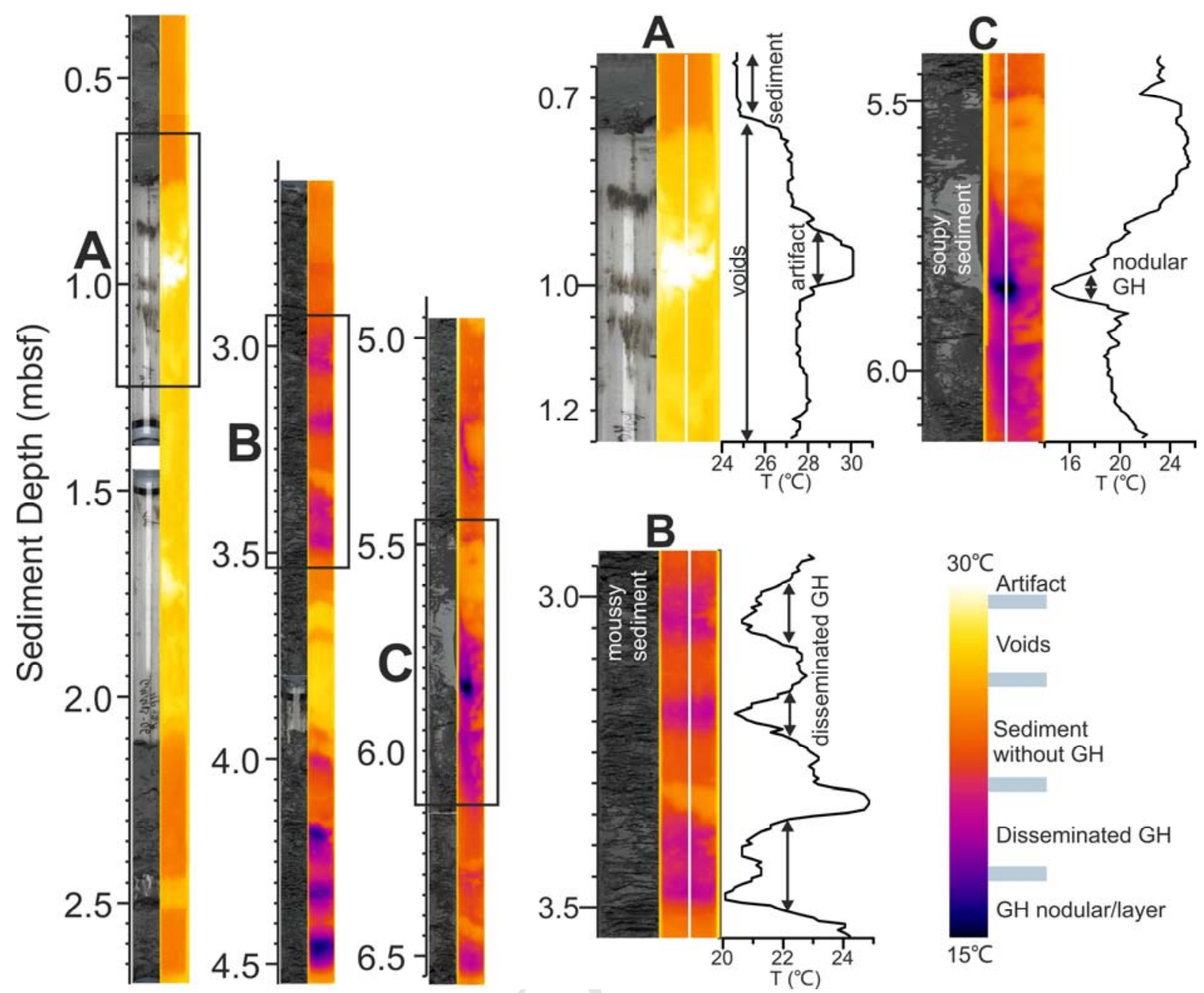


\section{ACCEPTED MANUSCRIPT}
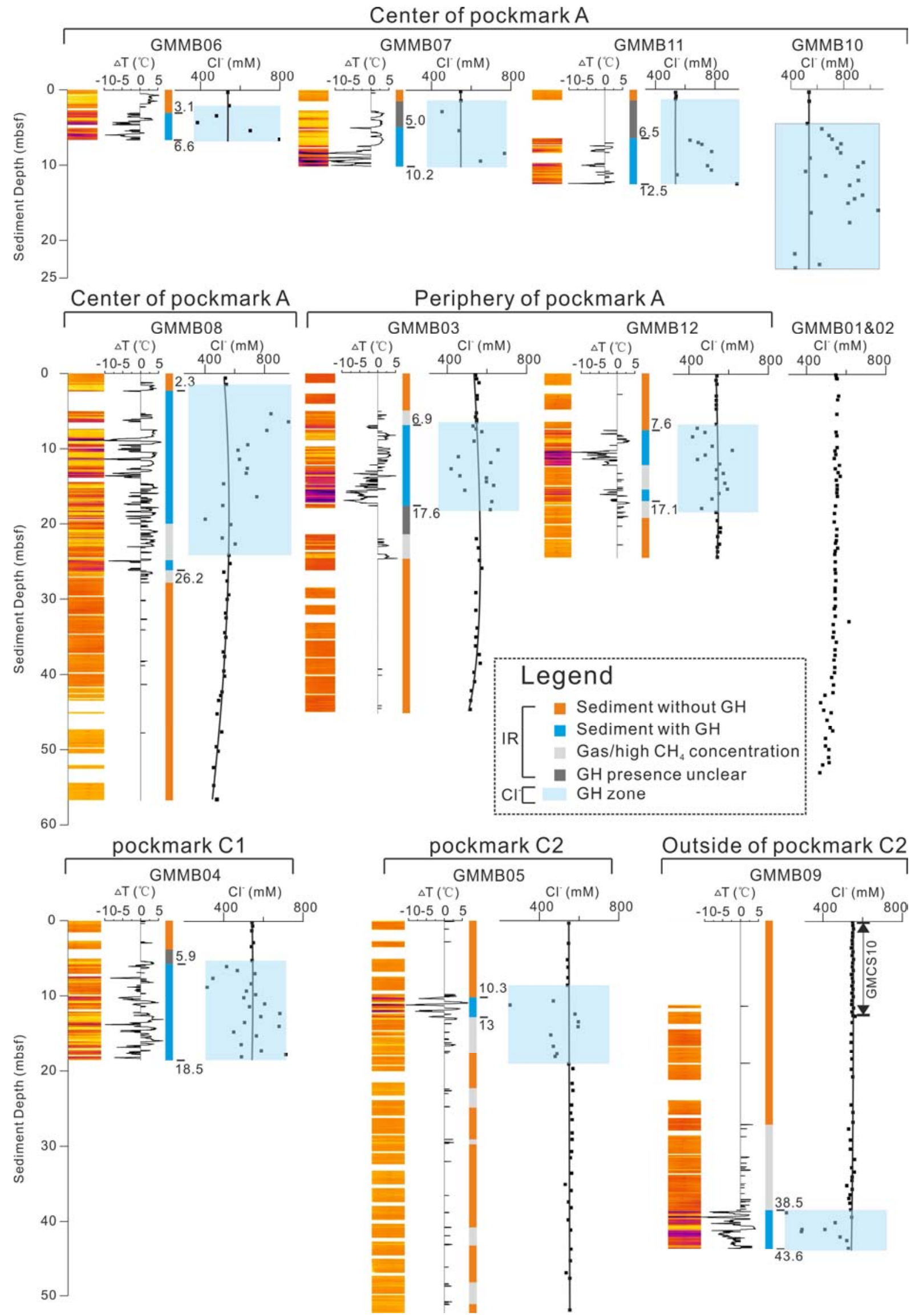


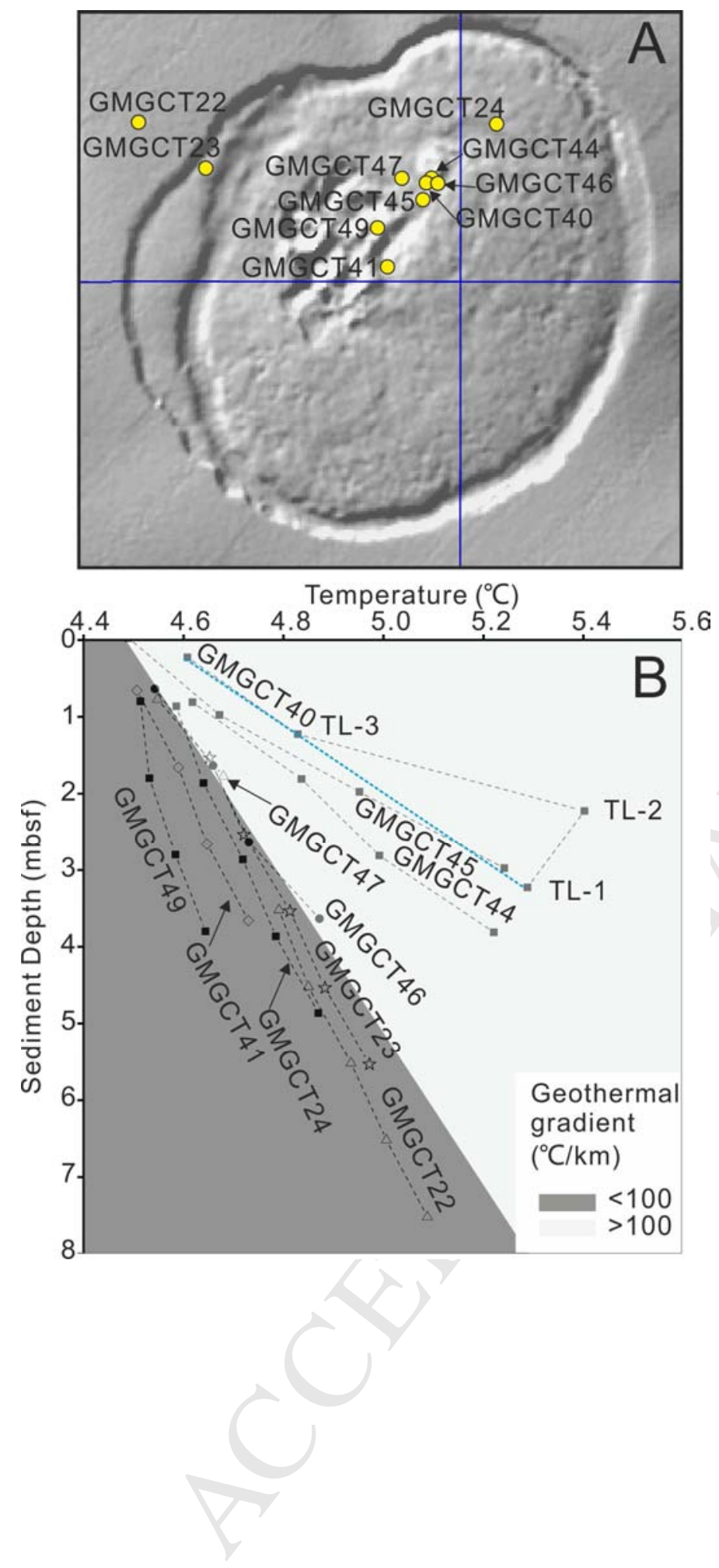




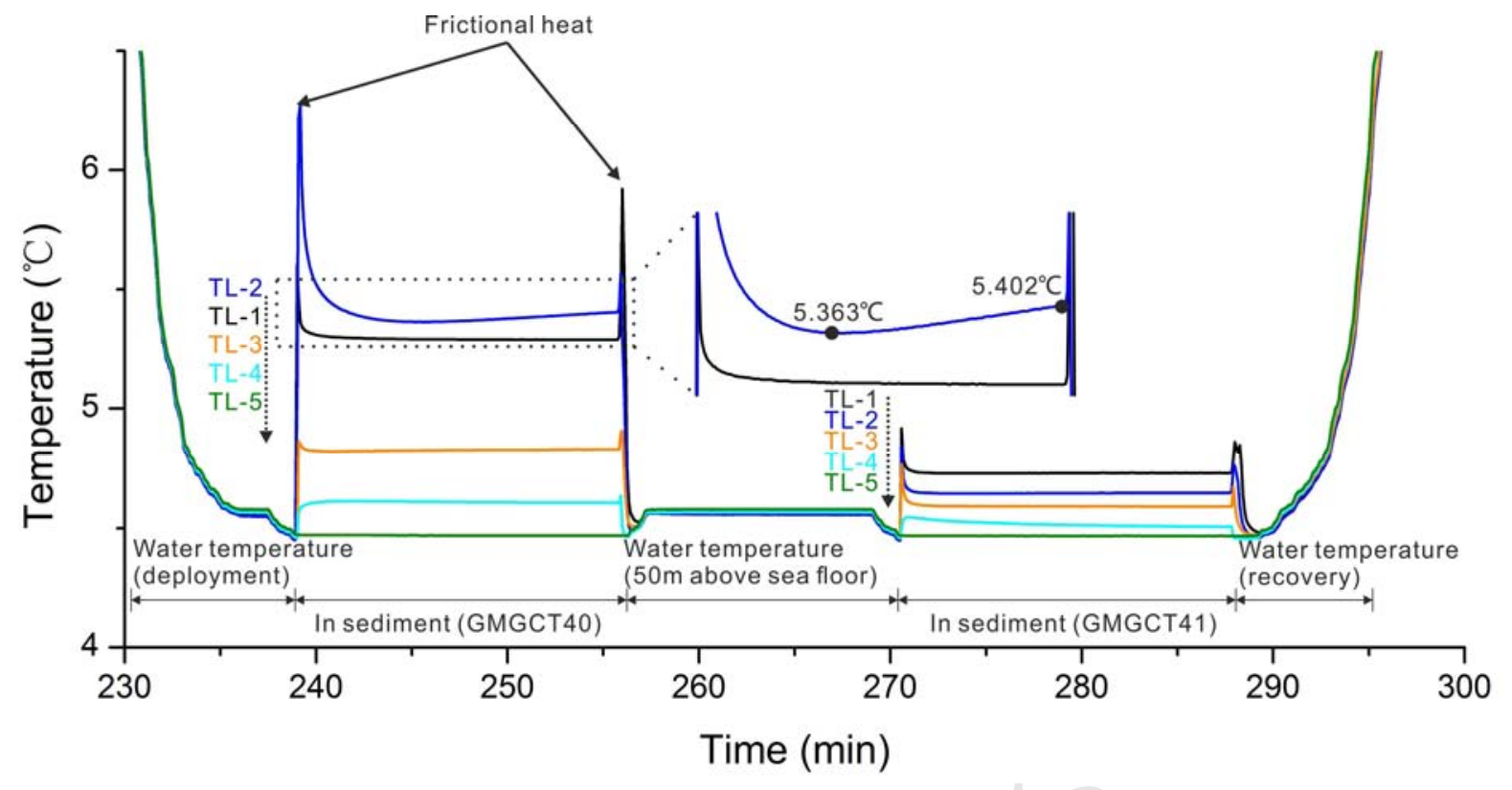



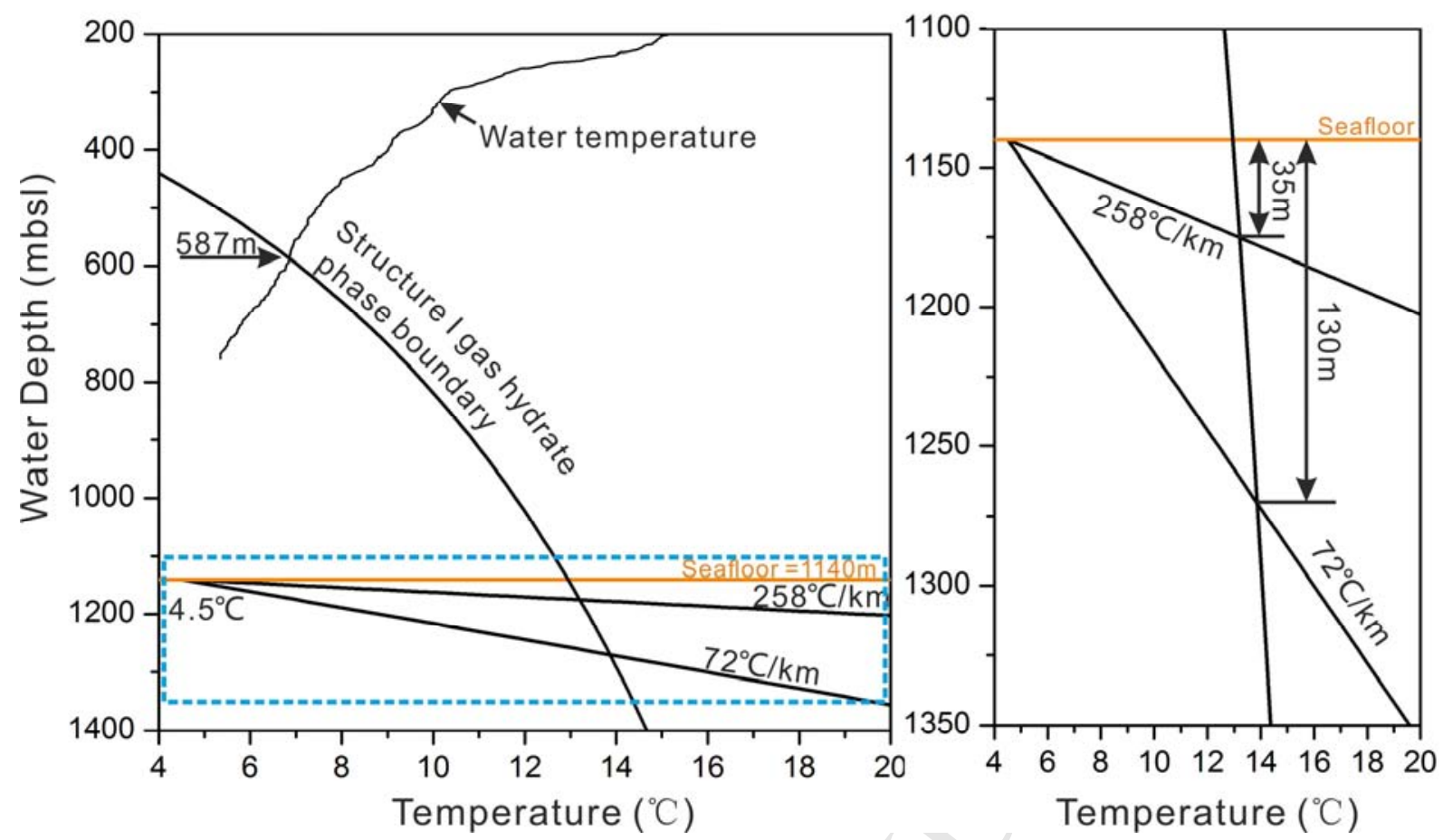

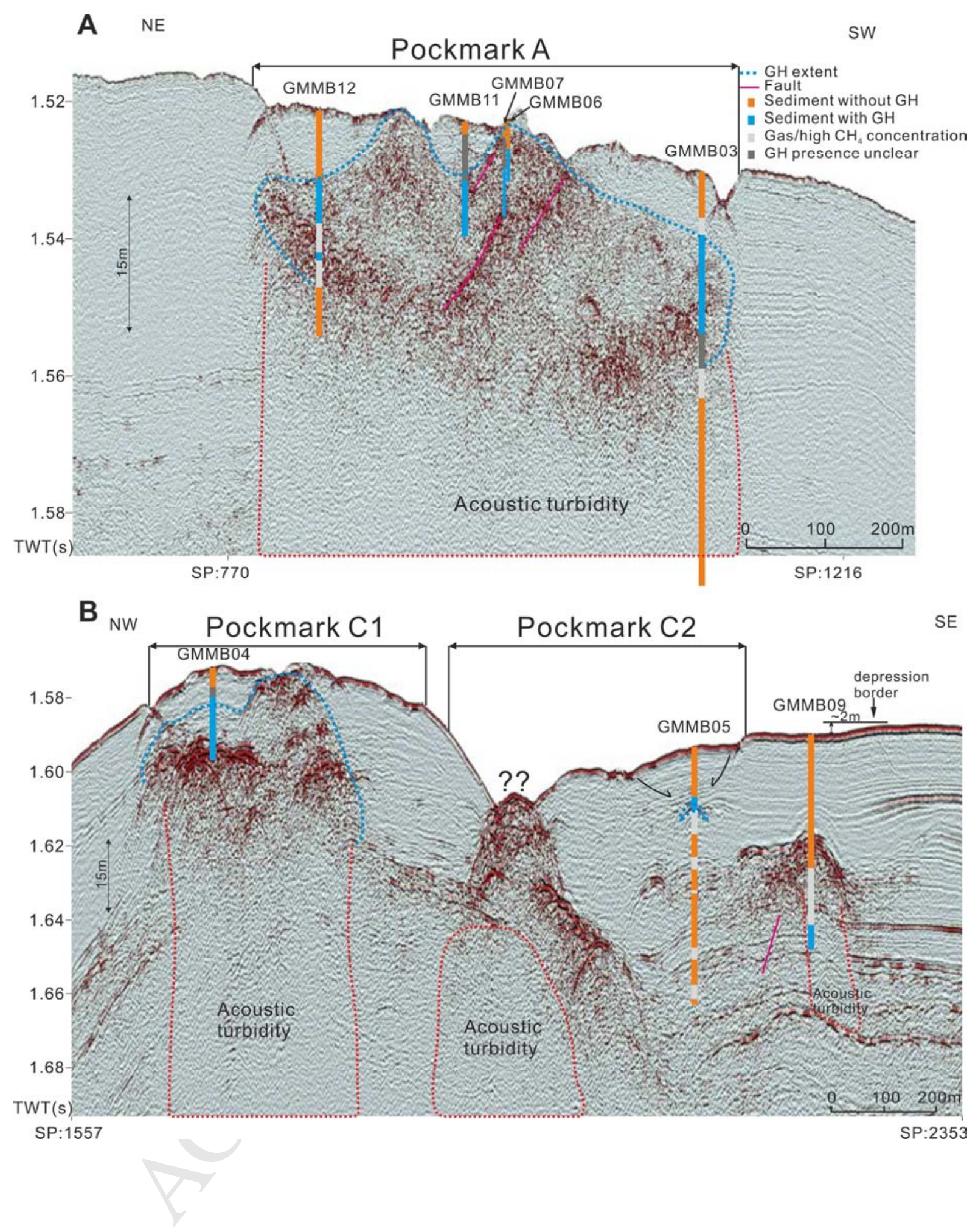
A
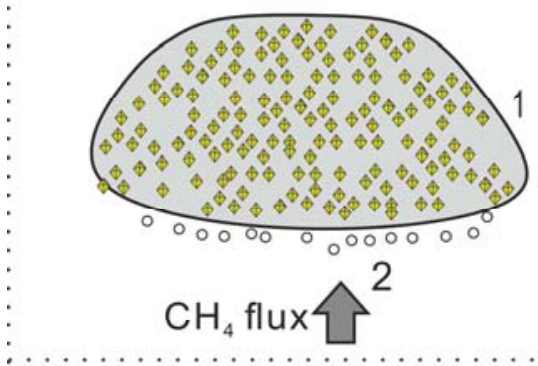

B

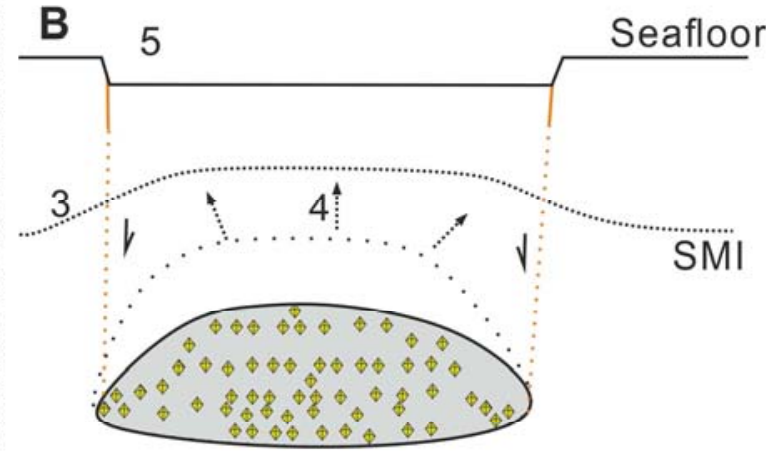

D

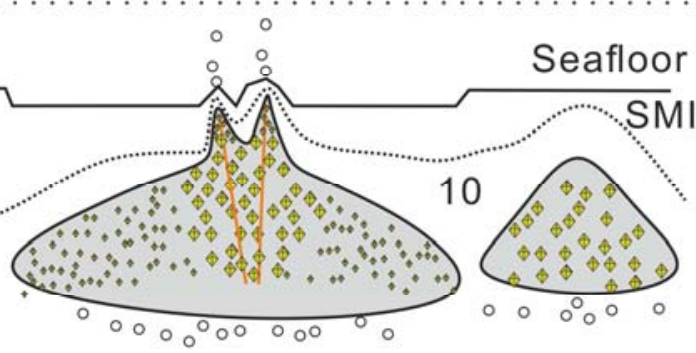

$\mathrm{CH}_{4}$ flux

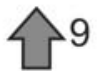

\section{Legend}

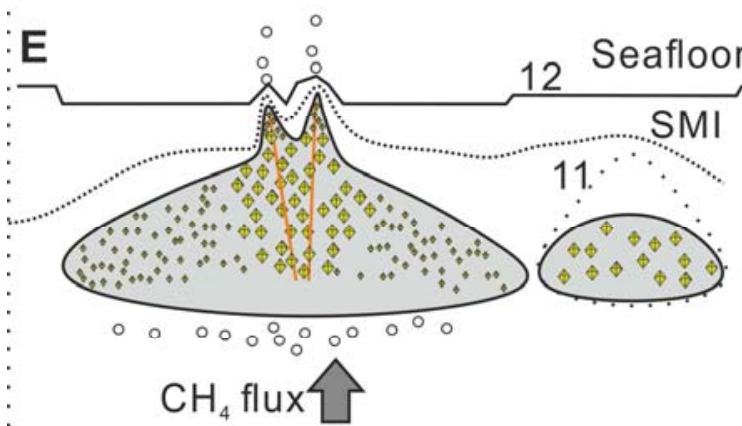

1. Gas hydrate accumulation

2. Gas accumulation below gas hydrate

3. Downward shifting of SMI

4. Dissolution at the top of the gas hydrate

5. Sea floor depression

6 . Fracture formation

7. Hummocky sea floor in the center

8. Bubble emission

9. Methane flux in the vicinity of the pockmark: 10-12. Repetition of stage $A$ 
Highlights:

1. Pockmarks on the Nigerian continental margin were investigated for gas hydrates

2. Long sediment cores were recovered with the portable MeBo drill rig

3. Infrared and pore water chloride measurements revealed gas hydrate distributions

4. Geothermal gradients in the pockmark center up to five fold higher than at the rim

5. Fluid flow and gas hydrate dynamics influence the evolution of pockmarks 